\title{
1. Macroeconomic lessons from the past decade
}

\section{J.W. Mason}

If nothing else, the decade since 2008 has been an informative one for macroeconomics. The Great Recession and its aftermath have offered a rich new trove of data, have taught several clear lessons, and have posed some new questions. A decade after the worst recession in its modern history, policymakers in the United States now confront the question - last faced in the 1990s - of what constitutes full employment and whether supply constraints might be more elastic than previously believed.

In this chapter, I lay out three broad lessons that can be drawn from the U.S. economic experience of the past decade. First, aggregate demand remains decisive for unemployment and related aggregate outcomes. A corollary is that fiscal policy remains effective. Second, the effects of demand cannot be limited to 'the short run'. The division between a long-run supply-side and a short-run demand-side, while it may be useful analytically, does not work as a description of real-world developments. Both the size of the labour force and productivity growth are substantially endogenous to aggregate demand. Third, the conventional tools of monetary policy are inadequate to stabilize output and employment. This inadequacy is often expressed as a problem of the zero lower bound, but the problem is broader than this.

All three of these lessons were, to some degree, taken on board by mainstream policymakers and economists in the years after the crisis. It is unclear to what extent there will be any lasting reorientation of macroeconomic policy, especially in the current political environment.

The remainder of this chapter discusses these three topics in turn.

\section{DEMAND STILL DRIVES (UN)EMPLOYMENT}

The decade from the beginning of the recession in December 2007 saw total growth in U.S. employment of 18 per cent. This is, by a wide margin, the least growth in employment for any ten-year period since the 1930s. To 
what extent was this the result of substitution away from labour in production, and to what extent of slower output growth? And to the extent that it was the latter, to what extent was this slower output growth driven by demand versus supply (or structural) factors?

Slow employment growth immediately after a recession has been recognized at least since Okun (1962) as the natural result of employment dynamics in which businesses reduce labour less than proportionately in downturn, leaving a pool of underutilized labour that must be drawn down in the first stage of the recovery. But these dynamics are hard to see in the moment. Slow employment growth following a downturn is repeatedly taken as a sign that structural factors - usually imagined as technological change - have rendered some large fraction of the labour force permanently unemployable. The $2008-2009$ recession was no exception - stories of zero-marginal-product workers, the great recalculation, and so on joined long-standing fears of automation as reasons that unemployment would remain high even as demand recovered. (See for instance Cowen and Lemke 2011.)

It is true that unemployment rose somewhat more during the recession itself than the historical Okun's law relationship would have predicted. This perhaps reflected increased flexibility in U.S. labour markets, which made it easier for employers to reduce staffing as output fell (Reich 2012). But once output began to rise again, unemployment actually fell faster than the historical relationship with output growth would have implied. So, substitution away from labour does not seem to have played any role in the weak labour market of the past decade. The slow growth in output after the expansion is more than sufficient to explain the slow fall in unemployment; there is no need to look to robots or other technological factors to explain persistently high unemployment. (Another way of looking at this: stories about job-destroying automation and so on require an acceleration of productivity growth; but productivity growth has in fact been historically slow.) The Beveridge curve similarly shows a familiar story of labour market slackening and tightening. Apart from the anomalous rise in unemployment in 2010, the strongly correlated movement of the unemployment and vacancy rates suggests unemployment was high simply because employers didn't need more workers; there is no need to look for reasons why some part of the population has become permanently unemployable (Jayadev and Konczal 2011).

The experience of the last decade offers no obvious support for a focus on labour-market interventions to bring down unemployment, whether the further liberalization proposed from the right or the federal jobs guarantee proposed from the left. To recreate the labour market performance of the late 1990s, recreating late 1990s growth should be sufficient. As Bivens 
(2017) argues, a 'high-pressure economy' will not only boost output and employment, the historical record suggests it will disproportionately benefit those at the back of the hiring queue.

The natural next question is whether slow growth is due to supply or demand constraints. There are several reasons to think that it is mostly or entirely demand. First, the failure to close the gap with the pre-recession trend; second, the absence of any of the usual macroeconomic indicators of tightening supply constraints; and third, the weakness of a demographic explanation for slow employment growth.

By official measures, the output gap took eight years to fully close, with output reaching potential by the second quarter of 2017. But this closing of the output gap was entirely due to downward revisions of potential output. Using estimates made in 2008, 2017 output remained 11 points below potential - a larger gap than at the bottom of the recession in 2009 (Mason 2017). Comparing current per capita output to the pre-2008 trend implies a similar gap. This is by far the largest deviation from trend in the post-1945 period.

The deviation of GDP from its long-run trend is already a problem for claims that the economy is now operating at full potential. There is little question that the financial crisis, collapse of the housing market, mass unemployment, and general fear and uncertainty of the recession period itself depressed aggregate demand - that is, they reduced households' and businesses' desired spending. But if the sharp fall in output of 2008-2009 was driven by demand-side factors, logically there should have been some bounce-back once those conditions depressing desired spending were removed.

The most obvious supply-side explanation for the slower growth of the past decade is a deceleration in labour force growth. Labour force growth is often regarded as a straightforward matter of demographics, plus some equally slow-moving institutional factors like migration and norms around women's participation in paid work. It is certainly true that the age distribution of the U.S. population has been shifting upward and that, historically, labour force participation rates decline with age above 50 or so. But a careful examination of the data does not support the view that demographics explains the slowdown in output growth.

Between 2000 and 2016, the U.S. employment-population ratio declined by about five points, of which four points came since 2007. If we group the population by age and sex, we find that three points ( 2.5 since 2007) of that decline have reflected lower participation rates within demographic groups, while two points (1.5 since 2007) reflect changes in the composition of the population (Mason 2017). The conclusion that at most half the decline in labour force participation is attributable to aging is shared by 
most studies of this question, including the Council of Economic Advisors (CEA 2014) and Dantas and Wray (2017). At the same time, however, education levels have been rising, and education is positively correlated with labour force participation. If we include education as a demographic variable, we find that these two effects almost exactly cancel out, leaving only a minor demographic effect - less than half a point out of the fivepoint total decline (Mason 2017).

While the aging of the population can, in an accounting sense, 'explain' close to half of the decline in labour force participation, we should be wary of taking this to mean that the decline was inevitable or independent of demand conditions. Variation in labour force participation by age is not especially stable over time, and in fact shifted significantly over the past 15 years. The modest fall in overall labour force participation reflects from much larger offsetting changes in particular age groups: participation among those 55 and older has increased by five points, while among those 24 and younger it has fallen by ten points. These large within-group changes make it clear that participation rates by age are not a hard structural constraint.

More broadly, there is no reason to imagine a fixed, 'normal' participation rate for a given demographic group. The large increase in women's labour force participation between the 1950s and 1980s, for instance, would not have been predictable on demographic grounds. And while the postwar United States has not seen sustained demand shocks on the level of the Great Recession, history does suggest that large demand shifts can have large, persistent effects on labour force participation rates. The fall in employment in the 1930s, for instance, reflected not only elevated unemployment rates but also a large fall in measured participation rates; participation then rose even more sharply with the 'effectively unlimited labour demand' during the war (Mathy 2018). Arguments implying that the United States today is at potential would, in 1940, have ruled out the large increase in employment that took place during the war.

Assessing the relative importance of demand conditions versus autonomous technological factors in the slow growth of labour productivity is more difficult. But if we take a step back and look at the overall macroeconomic situation, it is hard to avoid the conclusion that there has been a large and persistent fall in desired spending, i.e. aggregate demand.

Most heterodox as well as mainstream macroeconomic models suggest that while declines in either aggregate supply and demand growth will be associated with decelerations in output, the latter will be associated with slower price growth as well, while the former will be associated with fast price level growth. Supply constraints also imply an increase in the relative price of the scarce factors, so to the extent that the negative supply shock 
is supposed to include a demographic component, we should see a rising rather than a falling wage share. Furthermore, a negative supply shock does not, in itself, explain why desired spending fell along with it. The conventional view is that policy must adjust in a contractionary direction in response to a negative supply shock, to bring the desired path of spending down to the new, lower path of potential output. Yet both monetary and fiscal policy during the recovery have been exceptionally expansionary.

To believe that the slow growth over the past decade is primarily a supply-side phenomenon, we need not just one but a series of coincidences. Just as the economy recovered from the financial crisis, there was a steep slowdown in employment driven by demographic change. And at the same time, there was an unrelated slowdown in the pace of technological innovation. In addition, there must still have been an independent fall in demand to explain why the negative shocks to labour and technology did not lead to the higher inflation that the textbook predicts. And the timing has to be perfect: if the demographic decline in the labour force had come a few years earlier, there would have been no rise in unemployment during the recession, while if it had come a few years later, we would still be looking at high unemployment today. Since we need a fall in demand in any case, Occam's razor suggests we should prefer stories in which that drives everything else: a weak labour market discourages labour force participation, while weak demand in product markets and stagnant wages together discourage productivity-boosting innovation. Rather than a precisely synchronized series of unobservable shocks, this story requires just one shock, which we have in fact observed in the form of the end of the housing boom and the financial crisis.

The need to look at the full macroeconomic picture to distinguish supply from demand was expressed forcefully by DeLong and Summers (2012). They argue that interpretations of the fall in GDP as a decline in potential are missing an 'elementary signal extraction point': a fall in potential output implies a simultaneous fall in production and increase in inflation. Just as a simultaneous fall in the price and quantity sold of a given good can't be explained by a fall in supply of it but only by a fall in demand for it, a simultaneous slowdown in production and prices in the economy as a whole suggests a fall in aggregate demand, not in aggregate supply.

If weak demand is responsible for slow output growth, it follows that increasing the flow of spending is both necessary and sufficient to raise output and employment. This suggests a larger role for fiscal policy, and indeed a range of both mainstream and heterodox empirical studies over the past decade have found large, positive fiscal multipliers. This is one of the few areas where the crisis seems to have led to a significant shift in mainstream macroeconomics, at least in its more policy-oriented precincts, 
with a broad recognition that fiscal multipliers had been systematically underestimated in the past (Blanchard and Leigh 2013). Mainstream policymakers are now at least receptive to a 'new view' in which fiscal policy has an important role in stabilizing output and employment (Furman 2016).

A further question is whether fiscal policy, even if effective, may be limited by the need to issue new debt to finance it. A decade ago, this was unquestioned in the mainstream, and widely accepted among heterodox writers as well. Today there is less consensus on this point. One school of heterodox thought, which has gained increasing prominence over the decade, holds that for a country like the United States, the existing public debt is never a constraint on fiscal policy (Juniper et al. 2014). One need not accept this categorical claim, however, to believe that for the United States and other advanced countries, the debt ratio is not a serious constraint in practice. First, even if the idea of limited fiscal space is accepted in principle, it is hard to find in the data. Early in the decade strong claims were made for a hard tipping point (often 90 per cent of GDP) beyond which higher public debt would sharply and reliably depress growth. But the studies on which these claims were based were effectively debunked, and they seem to have receded from view (Herndon et al. 2014). Meanwhile countries throughout the advanced world have seen debt-GDP ratios rise to postwar highs while interest rates have remained at historical lows. Second, expansionary fiscal policy need not lead to a higher debt ratio, if interest rates fall or nominal growth rates rise. (Conversely even large fiscal surpluses can be associated with a rising debt ratio if nominal income falls, as has been dramatically shown in Greece.) If interest rates on public debt are lower on average than growth rates, then any fiscal position is sustainable, in the sense that the debt ratio will always converge to a finite value. There has been increasing recognition over the past decade that the historical evolution of debt ratios, in the United States and elsewhere, has been driven at least as much by the interest-growth rate differential as by changes in fiscal policy. If a central bank can control the interest rate on public debt - an entirely orthodox assumption - then it should be possible for the budget authorities to freely conduct fiscal policy while the central bank maintains the debt ratio at whatever level is considered socially desirable (Mason and Jayadev 2018). Finally, even if the interest rate is exogenously fixed, expansionary fiscal policy need not raise the debt ratio if its effect on output persists beyond the period in which it is undertaken. Even a modest spillover into future years is sufficient for increased public spending to 'pay for itself' in the sense of resulting in a lower long-term debt ratio (DeLong and Summers 2012). 


\section{THERE MAY BE NO ECONOMICALLY MEANINGFUL LONG RUN}

The conventional distinction between a demand-determined short run and supply-determined long run hinges on the idea that the economy's productive potential evolves independently of the flow of spending. Analytically, this requires a sharply-defined hierarchy of 'fast' and 'slow' variables, such that the latter can be treated as exogenously fixed with respect to the former. Conceptually, it requires us to believe both that technological change, labour force growth, and other supply-side variables evolve independently of current employment and output, and that demand reliably converges to supply-determined potential. Empirically, it requires some strategy to measure potential output independently of current output.

On the empirical level, the traditional approach has been to use some measure of trend, such as the popular Hodrick-Prescott filter, such that longer-term movements in output are attributed to potential while shorter-term movements are attributed to demand. This is the procedure used to produce most official estimates of potential output. ${ }^{1}$ The obvious flaw in this approach, as a number of critics have pointed out, is that it turns sustained deviations in output growth into shifts in potential by assumption. If output growth slows for whatever reason, trend- or filterbased measures will necessarily show a similar deceleration in potential output (Rosnick 2016). The Hodrick-Prescott filter has defects beyond the generic issues with trend-based estimates of potential - in particular, it puts disproportionate weight on recent observations (Hamilton 2018). Alternative measures of potential suggest a much larger gap between current output and potential than the official measures (Coibion et al. 2017). But the problem exists with any trend-based measures of potential, unless one has decided ex ante that demand effects cannot be persistent.

Conceptually, there are good reasons to doubt that growth in the labour force or in labour productivity can be safely regarded as independent of demand conditions. Hysteresis in labour markets is well supported empirically and at least somewhat accepted in mainstream theory. A common definition is offered by the New York Fed: 'extended periods of high unemployment [that] lead to skill losses among workers, reducing human capital and lowering future output' (Acharya et al. 2016). A substantial effect of unemployment, especially long-term employment, on future employment and income prospects is plausible and well attested. While the postwar United States has not seen sustained demand shocks on the level of the Great Recession, history does suggest that large demand shifts can have large, persistent effects on labour force participation rates. The fall in employment in the 1930s, for instance, reflected not only elevated 
unemployment rates but also a large fall in measured participation rates (Mathy 2018).

Conversely, hysteresis implies that periods of low unemployment should see rising labour force participation. With measured unemployment falling below 4 per cent in 2018, we should now be seeing signs of this. And indeed, as of the most recent data available at this writing (December 2018), labour force participation is up half a point over the past year, to its highest post-recession level - a sharp rebuke to those who claimed declining participation was an inevitable result of demographic change.

Persistent effects of demand on productivity growth are less discussed in the mainstream. One common argument for seeing the productivity slowdown as a negative technology shock is that it is simply the flip side of the positive shock of the 'tech boom' of the 1990s. In this view, the fact that the slowdown in productivity was not predicted before the recession should not be seen as evidence that it is the result of the recession. Rather, it is simply the correction of an earlier, mistaken extrapolation from a period of exceptional productivity growth (Gordon 2016).

On the other hand, the decline in the labour share is often understood to reflect a change in productive technology that encourages substitution of capital for labour. This may or may not be a reasonable way to think about the longer-term trend in factor shares. But it faces obvious problems as applied to the past decade in the United States (and other countries with similar experiences), as this is the same period that writers like Gordon (2016) say has seen a decline in productivity growth thanks to the exhaustion of information technology. In isolation, stories that explain a falling wage share by rapid technological progress, and falling productivity growth by slow technological progress, may each seem plausible. But both cannot be true simultaneously.

A link from demand to productivity has long been discussed in heterodox work, often under the rubric of Verdoorn's law. Besides the pure increasing-returns story, a number of possible mechanisms might link productivity growth to demand conditions. A brief list of possible links would include:

- Less pseudo-employment. In any economy, there are activities that are formally classified as employment but are not work in any substantive sense. Robinson (1937, pp.61-74) described these kinds of pseudo-jobs as 'disguised unemployment'. Her examples were someone who gathers firewood in a poor country or sells matches on street corners in a richer one. Work in family businesses, self-employment, and commission-based work might also fall into this category. (One of the few attempts to measure this kind of 
disguised unemployment is Eatwell (1997).) These activities absorb people who are unable to find formal jobs; the marginal product of additional workers here is very low. If higher demand draws people from this kind of disguised unemployment back into conventional jobs, measured productivity will rise.

- More capital-intensive production. For those accustomed to thinking in terms of a production function, the most natural explanation for changes in labour productivity is changes in the capital stock per worker. For heterodox writers, sceptical of the idea of a physical stock of capital and more attuned to the sociological complexity of the production process, it is not a simple matter of adding a little more capital and a little less labour to the bouillabaisse, in Leijonhufvud's (1986) memorable metaphor. But there are still many cases where it is not unreasonable to imagine a production process carried out with more (or better) machines, implying higher output per worker. Insofar as investment responds to demand conditions, this will show up as a demand-driven change in productivity. The accelerator principle that 'investment generally follows overall demand' has seen some revival in mainstream policy discussions (Furman 2015).

- Innovation in response to demand and costs. Higher wages not only lead businesses to adopt new technology, they may also lead to a redirection of social resources towards developing less labourintensive techniques of production. In addition, innovation is typically embodied in new capital goods and new firms, rather than from improvements of existing ones. Investment is highly cyclical, and it is much easier to start a new business in a boom than in a recession.

- Employment shifts towards higher-productivity sectors and firms. Aggregate productivity may rise even if output per worker is constant in each individual industry, if there is a shift in employment towards higher-productivity industries. This may happen for one of two reasons: first, higher wages will disproportionately raise costs for more labour-intensive sectors; second, the more income-elastic sectors may also be higher-productivity ones. Manufacturing, in particular, is both more income-elastic and higher productivity than services. Meanwhile, within a given industry firms employ technology and capital equipment of a range of vintages and efficiencies. To grow, more productive businesses must bid away workers and other inputs from incumbent firms, requiring a wage significantly above the going rate. In this sense, higher wages are an integral part of productivity growth. 
- Increasing returns. It may be that output per worker rises at the firm, industry, or economy-wide level when the amount being produced increases. It's worth noting that increasing returns is an area in which the intuition of people with economics training diverges sharply from people in the business and policy worlds. In many contexts outside economic theory, it is obvious that unit costs fall as more is produced.

While labour productivity - and the conditions of production in general are strictly segregated from demand and business cycle analysis in the mainstream, heterodox writers have long explored the possibility that output per worker might systematically vary with demand (Storm and Naastepad 2013). It is important, however, to think carefully about what kind of substantive relationship might underlie a model's formal relationship between output and productivity. For example, if we imagine the link operating through higher capital per worker (in whatever sense), we would expect that low unemployment could yield a one-time shift to a higher level of output per worker. But if we imagine the link operating through a more favourable environment for innovation, then low unemployment might be associated with persistently faster productivity growth. General formulations like 'a system that is growing fast is forced to innovate' (Jeon and Vernengo 2008), while pointing in the right direction, need to be grounded in sociologically rich, empirically-based accounts of the concrete linkages between demand and productivity growth.

Whatever the exact mechanisms, if demand conditions can have persistent effects on labour supply and/or productivity, this has serious implications for both policy and theory.

On the policy side, most straightforwardly, it means more space for expansionary policy. Low measured unemployment rates are not a sign of approaching supply constraints if the labour force itself is highly elastic. The elasticity of labour supply and productivity helps explain why measured unemployment has been able to fall to historically low levels without, as of mid-2018, any rise in inflation. Endogenous supply growth also implies higher costs for demand shortfalls, and lower costs for overshooting supply constraints. Negative demand gaps imply lower output and employment in future years, as well as this one, while the inflationary and other costs of overheating will be offset by higher output in future years, as aggregate supply adjusts upward. This means that policy should worry more about closing output gaps and less about inflation, a view that has made some headway in policy discussions. For example, Blanchard et al. (2015) observe: 'To the extent that hysteresis is present, it implies that deviations in output from its optimal level are much longer lasting and 
thus more costly than usually assumed. The implication is straightforward, namely that monetary policy should react more strongly to output movements, relative to inflation.'

The presence of hysteresis and what we might call anti-hysteresis (demand-induced increases in potential output) do not merely favour more expansionary policy, they also complicate policy decisions. The delegation of macroeconomic policy to independent central banks was based on the premise that managing aggregate demand did not involve any substantial trade-offs, and so did not pose political questions. A central building block of the modern consensus view was that there is no meaningful trade-off between inflation and unemployment - attempting to raise demand beyond potential will produce at best small and transitory increases in output and employment, while permanently raising inflation. In a world with hysteresis, the opposite is true: raising demand above (current or short-run) potential will produce only temporary inflation, until supply catches up, but it will produce permanent gains in output (Ball 2009). In this case there is no avoiding the trade-off between the policy goals of price stability and maximum employment and output.

Analytically, the first casualty of hysteresis is the idea of a labour supply. Instead, we may imagine a hierarchy of proximity to employment. The short-term unemployed are the closest, followed by the longerterm unemployed, employed people seeking additional work, discouraged workers, workers disfavoured by employers due to ethnicity, credentials, etc. Beyond this are people whose claim on the social product is not normally exercised by paid labour - retired people, the disabled, full-time caregivers - but who might come to be if labour market conditions were sufficiently favourable. Even further out, migration (both inward and outward) is also responsive to some degree to labour market conditions. There is no place within this gradient to draw a line around 'the labour force'. Transitions between unemployment and employment are not today - if they ever were - sufficiently more responsive to labour-market conditions than transitions between other statuses to make the concept meaningful. Of course, this is not news, but what we have learned is that this fuzziness is not a second-order detail that can be safely abstracted from. Formally, it seems, we should think not of an exogenous labour supply, but of a labour supply that is more or less elastic in response to labour-market conditions.

Similarly, technological change must also be thought of as responsive to demand conditions, as well as to investment - which itself is responsive to demand via the accelerator principle. To capture this, we cannot make production technology a fixed parameter.

Endogenizing labour supply and production technology may seem technically straightforward even if it requires modifying many widely-used 
macro models. But it poses a deeper problem. The long run in economic models means, formally, a length of time for some set of endogenous variables (e.g. the capital stock) to have fully adjusted to the exogenous ones. But in a world where labour and technology are responsive to demand conditions, it is not clear what are the exogenous variables we should think of the long-run position as being adjusted to. It may not be sensible to think of macroeconomic variables as being partitioned into fast and slow ones, such that the latter can be treated as exogenous for the behaviour of the latter. Employment, the labour force, output, the capital stock, and technology may all adjust to each other, on comparable time scales. Such a system will of course still have dynamics that can be formally modelled. But it will have no economically meaningful long run.

Again, there is nothing new here in principle. But what we have learned is that the division between endogenous and exogenous, or fast and slow, macroeconomic variables commonly used in heterodox as well as mainstream work, may not work even as a first approximation - it may abstract away from essential features of the developments we wish to explain. In this case, we may conclude that the techniques of formal modelling are best reserved for short-run, static analysis only. When we wish to discuss the longer-term evolution of capitalist economies, over periods of decades to centuries, we may do better to skip the systems of equations and focus on concrete historical description and accounting.

\section{CONVENTIONAL MONETARY POLICY IS INSUFFICIENT TO MANAGE AGGREGATE DEMAND}

A third lesson of the past decade is that central banks' macroeconomic role cannot be reduced to setting a single interest rate. This is both because the interest-rate instrument is inadequate to hit the conventional price-stability target, and because it is now clear that macroeconomic stabilization involves a number of targets, which are not equivalent to each other.

Before 2008, both academic macroeconomics and macroeconomic policy were strongly committed to the notion that conventional monetary policy, operating through a single overnight interest rate, was fully sufficient to offset any fluctuations in aggregate demand. The complacent view of future Obama administration CEA chair Christina Romer, offered on the verge of the crisis, is typical: 'The Federal Reserve is directly responsible for ... the virtual disappearance of the business cycle in the last 25 years ... The story of stabilization policy in the last quarter century is one of amaz- 
ing success ... We have seen a glorious counterrevolution in the ideas and conduct of short-run stabilization policy' (Romer 2007). Macroeconomics textbooks at both the undergraduate and graduate levels were organized around models in which a central bank setting a short-run interest rate according to an appropriate policy rule would fully offset demand shocks and ensure an optimal adjustment to supply shocks. To a lesser but still substantial extent, macroeconomic policy debates were also focused on a single short-run interest rate instrument.

While this narrow vision of macroeconomic policymaking appeared to work reasonably well in the United States and other developed countries in the two decades or so before 2007, today it is clear that it is an inadequate description of what central banks have been doing, let alone what they should be doing. Careful students of monetary policymaking have always had doubts about the straightforward transmission mechanism linking the policy rate to broader macro outcomes (Hannsgen 2004). But the crisis gave those doubts wider purchase. By 2011, Olivier Blanchard (then chief economist of the IMF) could write:

Before the crisis, mainstream economists and policymakers had ... convinced ourselves that there was one target, inflation. There was one instrument, the policy rate. And that was basically enough to get things done. If there is one lesson to be drawn from this crisis, it is that this construction wasn't right ... The fact is that there are many targets and there are many instruments. (Blanchard 2011)

The most obvious reason for scepticism about the old model of monetary policy is the manifest weakness of the interest rate instrument. The most straightforward evidence for this is the depth of the downturn itself, and the weakness of the recovery that followed, despite what was, by conventional measures, exceptionally expansionary policy. By the BEA's official measures, the cumulative output gap in the decade 2008-2017 amounted to 25 per cent of GDP, the largest cumulative gap of any postwar cycle, making a mockery of the idea of central-bank driven 'great moderation'. And if the ideas of hysteresis discussed in the previous section are valid, then the true gap was even larger. This failure is often discussed in terms of the 'zero lower bound' of the policy rate. But this is a one-sided way of looking at it: we must also ask why rates below zero were needed in the first place. As a matter of logic, if a much larger than expected reduction in rates is needed to keep the economy at full employment, then either the demand shocks are larger than previously believed, or the effect of a given change in rates is smaller (or of course both). These underlying conditions need to be a focus of policy discussions, and not just mechanisms for moving the policy rate (farther) below zero. 
It's important to keep in mind that the large negative output gaps of 2008-2011 came while the policy rate was at 0 , compared with 5.25 per cent at the start of the recession, federal deficits reached 10 per cent of GDP, and the trade balance had moved several points towards surplus. This implies that the underlying fall in demand was larger than the ultimate fall in output. If we accept conventional estimates of the fiscal multiplier and interest-elasticity of output, like those of Hervé et al. (2011), that implies a fall in autonomous private demand on the order of one-third of total private expenditure, over a period of two years. We should not rule out that private demand is this unstable. But such a large implied fall in demand should also lead us to consider that the sensitivity of output to changes in the policy rate may be smaller than previously believed, perhaps close to zero.

One reason why changes in the policy rate might not have a strong effect on real activity is that it is only weakly linked to market interest rates, particularly the long rates that are most important for real activity. Over time, spreads between the policy rate and longer and riskier rates have grown both wider and more variable (Jayadev and Mason 2015). In the most recent recession, the Fed reduced the policy rate from 5.25 per cent in July 2007 to 0 by December 2008. Yet it would take another two years for ten-year Treasury bonds to fall even 1.5 points from their 2007 level. Baa corporate bond rates, a good indicator of rates facing large private borrowers, actually rose as the Fed cut rates during the crisis; as late as mid-2011, after more than two-and-a-half years of policy rates at zero, corporate bond rates were within half a point of their pre-crisis levels. The Keynesian tradition offers a number of explanations for the independence of long rates from short rates, going back to Keynes' observation that 'the [long] rate is highly conventional . . . phenomenon' whose 'actual value is largely governed by the prevailing view as to what its value is expected to be' (Keynes 2012, p. 202). But whatever the reason for the disconnect, it suggests that if monetary policy is to affect credit conditions for private borrowers, it cannot rely on the overnight rate but must target long rates directly. For Keynes, an 'offer by the central bank to buy and sell at stated prices gilt-edged bonds of all maturities, in place of the single bank rate for short-term bills' would be 'the most important practical improvement which can be made in the technique of monetary management' (Keynes 2012, p. 206). There is precedent for the Fed targeting longer rates: between 1942 and 1947, the Fed successfully maintained a 2.5 per cent ceiling on long-term government bonds (Hetzel and Leach 2001).

A second set of arguments for a broader conception of monetary policy going forward is that the macroeconomic outcomes of concern to the central bank cannot be reduced to a single target. Prior to 2008, textbook 
and, for the most part, policy macroeconomics was based on the idea of a 'divine coincidence' (Blanchard 2016). The same level of demand would result in output at its highest sustainable level, low and stable inflation, and full employment. Formally, this can be assured by definition: assuming there is some kind of relationship between output, employment, and inflation, potential output and full employment can be simply defined as the levels consistent with inflation at target. But the formalism is based, implicitly or explicitly, on a substantive claim about the economy: that most of the variation between the three aggregates is shared, and that the levels of output and employment derived from the formula conform to the conceptions of policymakers and the broader public about acceptable rates of unemployment and growth. The widely-discussed 'flattening' of the Phillips curve over the past decade has made this claim less viable. The stability of inflation not far below the Fed's 2 per cent target during the extended period of high unemployment after 2008 makes it clear that hitting the price stability target does not imply an acceptable employment performance. Conversely, the more recent fall in unemployment without any acceleration in inflation suggests that if the central bank continues to respond strongly to unemployment, it may be pursuing an objective other than its stated ones.

An obvious alternative reaction function is suggested by the familiar accounting identity:

percentage nominal wage growth $=$ inflation + productivity growth + per cent change in the wage share

If the central bank targets wage growth even in the absence of a link with inflation, then by definition it must be seeking to prevent a rise in either productivity growth or the wage share. While the former is implausible, the latter is not - there is a long history of public and private statements by central bankers that suggest a rising wage share would be regarded as undesirable, regardless of its effects on inflation (Mitchell and Erickson 2005). This evolution appears to have gone farther in Europe than in the United States, given the replacement of the Non-Accelerating Inflation Rate of Unemployment with the Non-Accelerating Wage Rate of Unemployment as a guide for policy; the elevation of competitiveness alongside price stability as a macroeconomic argument for wage restraint; and the focus on real unit labour costs - the latter being simply an obfuscated way of describing the labour share, to which it is identically equal (Felipe and Kumar 2014). In the United States, so far, the rhetoric of monetary policy has more consistently maintained that wage increases are undesirable only insofar as they herald rising inflation; but this will 
grow harder to sustain if the Fed continues to raise rates in response to low unemployment in the absence of any inflation signal.

As noted in the previous section, the presence of hysteresis also creates problems for the divine coincidence. If labour supply and/or productivity growth vary with unemployment, we can no longer assume that abovetarget inflation implies a positive output gap that can only be closed by lower demand. If allowed to persist, a positive output gap may instead eventuate in increased supply. This creates a challenging trade-off for monetary policy.

Additional problems for orthodoxy arise when we look at policy at a more disaggregated level. Whether or not they reliably affect real activity, changes in the policy rate certainly move asset prices and debt stocks. The asset price effect has gotten more discussion, with financial stability entering the lexicon as an argument for higher rates (Leijonhufvud 2009). But the latter may be important. Historically, the interest-rate growth-rate differential has been more important for changes in the federal debt-GDP ratio than changes in the fiscal position (Kogan et al. 2015). This is even more true of household debt. Indeed, the entire rise in household debt-income ratios since 1980 can be explained in accounting terms by the rise in effective interest rates relative to nominal income growth (Mason and Jayadev 2015). If debt ratios and/or asset prices are a concern for policymakers, they must be taken into consideration by rate-setters at the Fed.

To the extent that monetary policy does affect real activity, it is unlikely to be through changes in 'the' interest rate faced by the economy as a whole, but in the availability of credit for specific sectors and activities. The inadequacy of the conventional interest rate channel of policy has long been recognized by practitioners, even if it has yet to make its way into policy (Bernanke and Gertler 1995). Housing, in particular, has been relatively more sensitive to policy, with mortgage rates more closely linked to the policy rate and mortgage borrowing moving more with interest rate changes. The disproportionate sensitivity of housing to monetary policy may be the main reason why policy is not completely ineffectual; but it also means that policy changes are affecting the share of output devoted to housing as well as the overall level of output. Similarly, the Fed's exceptional interventions to support the housing market may have been undertaken to protect the credit system as a whole, but they have the effect of favouring credit to housing rather than to other sectors. It may be time to frankly acknowledge that monetary policy affects the direction as well as level of activity, and ask what kinds of activity are most deserving of support. It might, for instance, be wiser to channel credit towards decarbonization rather than towards the single-family housing sector. 
The financial crisis itself also calls into question the existing conduct of monetary policy, in two ways. First it demonstrated (not for the first time) the possibility of massive asset bubbles, and banking crises in their wake. The concerns this raises for monetary policy are obviously exacerbated if one believes monetary policy operates in large part through asset prices; and if one believes, as famously suggested by Summers (2014), that the advanced economies face a secular shortfall in demand, or secular stagnation, such that full employment is possible only in the presence of inflated asset prices. Second, the possibility of what certainly appears, ex post, as widespread mispricing of assets and misallocation of credit, should raise doubts about the private financial system's ability to direct credit even in normal times. Krugman (2016) suggests that this broader point about the efficiency of financial markets should be one of the main lessons of the crisis. The experience of the past decade suggests:

... a broader rationale for policy activism than most macroeconomists - even self-proclaimed Keynesians - have generally offered in recent decades. Most of them ... have seen the role for policy as pretty much limited to stabilizing aggregate demand. Correcting asset markets when they go wrong wasn't part of the mandate, because who were policymakers to claim that they were smarter than private investors? Once we admit that there can be big asset mispricing due to liquidity and collateral constraints, however, the case for intervention becomes much stronger...

Whatever one's priors about the relative merits of private versus public direction of finance and investment, the experience of 2008-2009 should shift them in favour of the latter. And if the private financial system cannot be trusted to direct society's surplus towards the most valuable uses, then, in the absence of other public financial institutions, central banks must play a more active role.

For all these reasons, it seems unlikely that monetary policy in the future will fit the textbook model of setting a single overnight interest rate. Quantitative easing, forward guidance and, probably, larger and more heterogeneous asset holdings, are already widely accepted as permanent parts of monetary policy for the foreseeable future (Friedman 2014). But it is unlikely that these relatively modest changes to orthodoxy will be enough for central banks to reliably achieve their goals. With respect to quantitative easing, even positive assessments of its effects suggest that it is too weak to play more than a supporting role in macroeconomic stabilization. One recent survey of empirical studies of QE finds that the median estimate is that purchases of bonds equal to 10 per cent of GDP would reduce long rates by eight tenths of a point (Gagnon 2016). This is not trivial, but it is quite small relative to the programme's size, and to the 
requirements of macroeconomic stabilization. Forward guidance appears even weaker; indeed, the idea that central banks can influence economic outcomes today by announcing policy changes somewhere in the future is 'more theological than practical' (Friedman 2014). It is based on models in which agents have qualitatively greater knowledge of the future than is available in the real world, and in which they are able to act freely on this knowledge thanks to the absence of exactly the kinds of financial frictions that make monetary policy necessary in the first place.

The implication is that central banks must be political. There is no way around weighing a variety of social priorities, and making judgements about the social value of the various activities in need of financing. Even if aggregate liquidity or average interest could be reliably set at the 'right' level, many individual borrowers would still get too little credit, and a few would get too much. As Stiglitz (2013) puts it frankly, 'Governments and central banks need to have explicit programmes to encourage lending to certain groups/sectors that are underserved.'

From the perspective of the pre-2008 consensus this sounds radical, but in a longer view it is not as much of a departure. Historically, macroeconomic demand management by central banks has involved a much broader range of both goals and tools compared to the pre-2008 orthodoxy (Epstein 2013). In the years after 2008, many central bankers have recognized that it is likely that future crises and/or prolonged demand shortfalls will require experimentation with a broader range of targets and instruments. In the words of the former Bank of England Monetary Policy Committee member Adam Posen (2013):

... you only need to look back at monetary history to see the obvious: central banks have engaged in extended periods of administrative guidance, of doing very active directed lending in particular sectors, and especially of engaging in market operations on financial assets other than government securities ... It is quite literally a prehistoric argument to assert that central banks are engaged in experimental, unprecedented, or somehow scandalous and dangerous policy maneuvers today.

During the financial crisis of 2007-2009, the Fed created special facilities to support lending in a range of other markets. To support markets for securitized auto loans and credit card loans, the Fed created the Term Asset-Backed Securities Loan Facility (TALF) in November 2008, which purchased nearly US\$50 billion of such securities. The Fed also created lending facilities to provide support to commercial paper, money-market funds, and securities broker-dealers (Price 2012). While conceived of as emergency measures, similar programmes could be adopted on an ongoing basis if there is reason to believe that the normal allocation of credit is 
inconsistent with social priorities, or with financial stability, or with the Fed's other macroeconomic objectives. In the long run, making the Fed a more reliable steward of the macroeconomy will require a reconceptualization of its place in the financial system. The clean separation of monetary policy, carried out by an independent central bank based on a simple policy rule, from other aspects of macroeconomic policy conducted by the elected government, is no longer viable - if it ever was.

\section{CONCLUSION}

Eighty years after Keynes first stated it in its modern form, the principle of aggregate demand remains profoundly subversive of received economic wisdom. Orthodox economic theory, in both its textbook and cutting-edge incarnations, is based on a framework in which economic problems are essentially about the allocation of scarce resources among competing ends. If output is constrained by demand, then this framework is inapplicable. A demand-constrained economy is operating far from the 'real' supply constraints analysed by orthodoxy, if indeed these constraints exist at all. Real resources are not scarce. The central economic problem is not allocation, but coordination. As a corollary, if the economy suffers from large-scale coordination problems, markets are evidently inadequate to coordinate our collective productive activity. All of this is profoundly unsettling to those brought up in the orthodox economics tradition.

Within mainstream macroeconomics, the 'freshwater' or real-business cycle school seeks to expunge demand entirely by explaining even shortrun fluctuations in output and employment by shifts in real productive capacities. The more policy-oriented parts of orthodoxy cannot dispense with demand entirely, so they seek to quarantine it as a purely short-run phenomenon that can be left safely to the management of the central bank.

The experience of the post-2008 decade suggests that demand cannot be so easily removed from its place at the centre of the macroeconomic stage. Despite efforts to explain the behaviour of employment in terms of demographics, technological change, or other 'real' or supply-side phenomena, it is hard to make sense of labour-market developments in the ten years after the crisis except in terms of shifts in aggregate spending. Nor can we safely assume that demand fluctuations are purely short term, so that the long-run evolution of the economy can be analysed in terms of the real dynamics of accumulation and exogenous technological and demographic change. The decade's weak growth in employment, productivity, and output appears to be due to a demand gap which persisted well beyond any reasonable 'short run', and as of this writing shows little sign 
of closing. A third lesson of the past decade is that macroeconomic policy cannot be reduced to setting a single short-term interest rate. It is now clear that the policy rate is a much weaker tool for stabilizing demand than had been believed in the years before 2008. It is also clear that in attempting to stabilize the path of output and employment, the central bank must also consider the effects of its actions on asset markets, the distribution of income, and the composition of spending.

The experience of the past decade has been taken, with reason, as vindication by writers in the Post-Keynesian and broader heterodox macroeconomics traditions. But they also pose challenges for heterodox approaches. Heterodox as well as mainstream writers have generally worked in terms of a single economy-wide interest rate. The short-run-long-run distinction is also widely used in heterodox macroeconomics. This is part of a longer-term shift within Keynesian macroeconomics away from cyclical fluctuations towards models of long-run growth. One lesson for heterodox macroeconomists may be that that this shift in attention has been carried too far. More broadly, the puzzles posed by the past decade's developments may be best approached by stepping back from highly aggregated formal models towards a more concrete level of analysis.

\section{NOTE}

1. This is true of the U.S. estimate, albeit indirectly: while the estimate itself is derived from a production function, key parameters, such as total factor productivity, are derived from a trend (Congressional Budget Office 2007).

\section{REFERENCES}

Acharya, Sushant, Julien Bengui, Keshav Dogra, and Shu Lin Wee (2016), 'Escaping unemployment traps', Federal Reserve Bank of New York Liberty Street Economics blog, November 16, 2016. Available at: http://libertystreeteconomics. newyorkfed.org/2016/11/escaping-unemployment-traps.html.

Ball, L. M. (2009), 'Hysteresis in unemployment: Old and new evidence', National Bureau of Economic Research, NBER Working Paper No. 14818.

Bernanke, B. S. and M. Gertler (1995), 'Inside the black box: The credit channel of monetary policy transmission', The Journal of Economic Perspectives, 9 (4), 27-48.

Bivens, J. (2017), 'A high-pressure economy can help boost productivity and provide even more room to run for the recovery', Economic Policy Institute, Washington, DC.

Blanchard, O. (2011), 'Monetary policy in the wake of the crisis', IMF, Macro Conference. Available at: http://www.imf.org/external/np/seminars/eng/2011/res/ pdf/ob2presentation.pdf. 
Blanchard, O. (2016), 'The Phillips curve: Back to the '60s?', American Economic Review, 106 (5), 31-34.

Blanchard, O. J. and D. Leigh (2013), 'Growth forecast errors and fiscal multipliers', American Economic Review, 103 (3), 117-120.

Blanchard, O., E. Cerutti, and L. Summers (2015), 'Inflation and activity: Two explorations and their monetary policy implications', National Bureau of Economic Research, NBER Working Paper No. 21726.

Coibion, O., Y. Gorodnichenko, and M. Ulate (2017), 'The cyclical sensitivity in estimates of potential output', National Bureau of Economic Research, NBER Working Paper No. 23580.

Congressional Budget Office (2007), 'The budget and economic outlook: Fiscal years 2008 to 2017', Washington, DC: Congressional Budget Office.

Council of Economic Advisors (2014), 'The labor force participation rate since 2007', Washington, DC: Executive Office of the President of the United States. Available at: http://scholar.harvard.edu/files/stock/files/labor_force_participation.pdf.

Cowen, T. and J. Lemke (2011), '10 percent unemployment forever?', Foreign Policy, January 6.

Dantas, F. and L. R. Wray (2017), 'Full employment: Are we there yet?', Public Policy Brief, Jerome Levy Economics Institute of Bard College.

DeLong, J. Bradford and Lawrence H. Summers (2012), 'Fiscal policy in a depressed economy', Brookings Papers on Economic Activity, Spring, 233-297.

Eatwell, John (1997), 'Effective demand and disguised unemployment', in J. Michie and J. Grieve Smith (eds), Employment and Economic Performance, Oxford: Oxford University Press, pp. 76-94.

Epstein, Gerald (2013), 'Developmental central banking: Winning the future by updating a page from the past', Review of Keynesian Economics, 1 (3), 273-287.

Felipe, J. and U. Kumar (2014), 'Unit labor costs in the eurozone: The competitiveness debate again', Review of Keynesian Economics, 2 (4), 490-507.

Friedman, Benjamin M. (2014), 'Has the financial crisis permanently changed the practice of monetary policy? Has it changed the theory of monetary policy?', NBER Working Paper No. 20128. Cambridge, MA: National Bureau of Economic Research.

Furman, Jason (2015), 'Business investment in the United States: Facts, explanations, puzzles, and policies'. Remarks by Jason Furman, Chairman of the Council of Economic Advisers, at the Progressive Policy Institute.

Furman, Jason (2016), 'The new view of fiscal policy and its application'. Remarks at the Conference 'Global Implications of Europe's Redesign', New York, October 5, 2016. Available at: https://www.whitehouse.gov/sites/default/files/page/ files/20161011_furman_suerf_fiscal_policy_cea .pdf.

Gagnon, Joseph (2016), 'Quantitative easing: An underappreciated success', Washington, DC: Peterson Institute for International Economics.

Gordon, Robert J. (2016), The Rise and Fall of American Growth: The U.S. Standard of Living since the Civil War, Princeton, NJ: Princeton University Press.

Hamilton, J. D. (2018), 'Why you should never use the Hodrick-Prescott filter', Review of Economics and Statistics, 100 (5), 831-843.

Hannsgen, G. (2004), 'The transmission mechanism of monetary policy: A critical review', Economics Working Paper No. 412, Jerome Levy Economics Institute of Bard College.

Herndon, T., M. Ash, and R. Pollin (2014), 'Does high public debt consistently 
stifle economic growth? A critique of Reinhart and Rogoff', Cambridge Journal of Economics, 38 (2), 257-279.

Hervé, K., N. Pain, P. Richardson, F. Sédillot, and P.-O. Beffy (2011), 'The OECD's new global model', Economic Modelling, 28 (1-2), 589-601.

Hetzel, R. L. and R. F. Leach (2001), 'The Treasury-Fed Accord: A new narrative account', Economic Quarterly - Federal Reserve Bank of Richmond, 87 (1), 33-55.

Jayadev, A. and M. Konczal (2011), 'The stagnant labor market: Some aspects of the bleak picture', Journal of Post Keynesian Economics, 33 (3), 435-450.

Jayadev, A. and J. W. Mason (2015), 'Loose money, high rates: Interest rate spreads in historical perspective', Journal of Post Keynesian Economics, 38 (1), 93-130.

Jeon, Y. and M. Vernengo (2008), 'Puzzles, paradoxes, and regularities: Cyclical and structural productivity in the United States (1950-2005)', Review of Radical Political Economics, 40 (3), 237-243.

Juniper, J., T. P. Sharpe, and M. J. Watts (2014), 'Modern monetary theory: Contributions and critics', Journal of Post Keynesian Economics, 37 (2), 281-307.

Keynes, J. M. (2012), The General Theory of Employment, Interest and Money, The Collected Writings of John Maynard Keynes Volume 7, Cambridge: Cambridge University Press.

Kogan, R., C. Stone, B. DaSilva, and J. Rejeski (2015), 'Difference between economic growth rates and treasury interest rates significantly affects long-term budget outlook', Washington, DC: Center for Budget and Policy Priorities.

Krugman, Paul (2016), 'What have we learnt from the crisis?' Presented at the Graduate Institute of International and Development Studies, Geneva, September 20. Available at: https://webspace.princeton.edu/users/ pkrugman/krugman_ geneva.pdf.

Leijonhufvud, A. (1986), 'Capitalism and the factory system', in R. Langlois (ed.), Economics as a Process, New York: Cambridge University Press, pp. 203-223.

Leijonhufvud, A. (2009), 'Out of the corridor: Keynes and the crisis', Cambridge Journal of Economics, 33, 741-757.

Mason, J. W. (2017), 'What recovery?: The case for continued expansionary policy at the Fed', Roosevelt Institute Working Paper.

Mason, J. W. and A. Jayadev (2015), 'The post-1980 debt disinflation: An exercise in historical accounting', Review of Keynesian Economics, 3 (3), 314-335.

Mason, J. W. and A. Jayadev (2018), 'A comparison of monetary and fiscal policy interaction under sound and functional finance regimes', Metroeconomica, 69 (2), 488-508.

Mathy, G. P. (2018), 'Hysteresis and persistent long-term unemployment: The American Beveridge curve of the Great Depression and World War II', Cliometrica, 12 (1), 127-152.

Mitchell, D. J. and C. L. Erickson (2005), 'Not yet dead at the fed: Unions, worker bargaining, and economy-wide wage determination', Industrial Relations: A Journal of Economy and Society, 44 (4), 565-606.

Okun, A. (1962), 'Potential GNP: Its measurement and significance', Proceedings of the Business and Economic Statistics Section of the American Statistical Association, 7, 89-104.

Posen, Adam (2013), 'Cheap talk is no alternative to inflation targeting', in $I S$ Inflation Targeting Dead? Central Banking After the Crisis, London: Centre for Economic Policy Research, pp. 59-65.

Price, David A. (2012), 'When the Fed conducts credit policy', Federal Reserve 
Region Focus (First Quarter). Available at: https://www.richmondfed.org/ /media/ richmondfedorg/publications/research/region_focus/2012/q1/pdf/ federal_reserve. pdf.

Reich, M. (2012), 'The rising strength of management, high unemployment and slow growth: Revisiting Okun's law', Working Paper, Political Economy Research Institute.

Robinson, Joan (1937), Essays in the Theory of Employment, Oxford: Basil Blackwell.

Romer, C. D. (2007), 'Macroeconomic policy in the 1960s: The causes and consequences of a mistaken revolution'. Talk at Lyndon B. Johnson Presidential Library, Economic History Association Annual Meeting, 2007.

Rosnick, D. (2016), 'Potential for trouble: The IMF's estimates of potential GDP', Issue Brief, Washington, DC: Center for Economic and Policy Research.

Stiglitz, Joseph E. (2013), 'A revolution in monetary policy: Lessons in the wake of the global financial crisis'. Presented at the 15th CD Deshmukh Memorial hosted by the Reserve Bank of India, Mumbai, India, January 3.

Storm, S. and C. Naastepad (2013), 'Wage-led or profit-led supply: Wages, productivity and investment', in M. Lavoie and E. Stockhammer (eds), WageLed Growth: Concept, Theories and Policies, London: Palgrave Macmillan, pp. 100-124.

Summers, Lawrence H. (2014), 'U.S. economic prospects: Secular stagnation, hysteresis, and the zero lower bound', Business Economics, 49 (2), 65-73. 